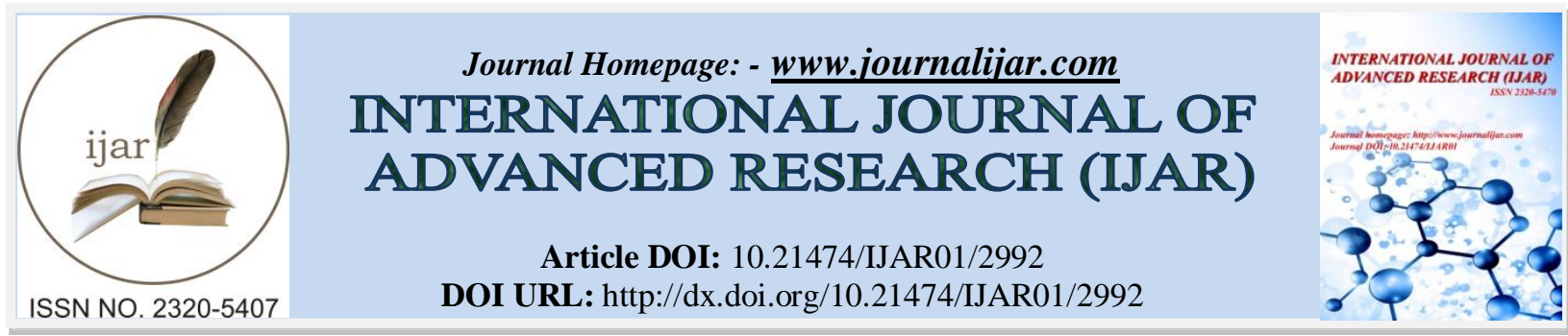

RESEARCH ARTICLE

\title{
A STUDY OF NEAR MISS OBSTETRIC EVENTS AND MATERNAL DEATHS IN A TERTIARY CARE HOSPITAL
}

Shilpa Dhingra ${ }^{1}$, Reena Yadav $^{2}$ and Chitra Raghudandan ${ }^{3}$.

1. Associate Professor, NDMC Medical College and Hindu Rao Hospital, Delhi.

2. Director Professor and Unit Head, Lady Hardinge Medical College and SSK Hospital, New Delhi.

3. Visiting Consultant Fortis Hospital Vasant Kunj, New Delhi and Eye Care Centre, C6/9,Safdarjung Development Authority, New Delhi.

\section{Manuscript Info}

-........................

Manuscript History

Received: 28 November 2016

Final Accepted: 27 December 2016

Published: January 2017

Key words:-

Maternal near miss events, Maternal

mortality, Severe acute maternal

morbidity, Maternal morbidity

\section{Abstract}

Introduction: Maternal Near Miss refers to a women who nearly died but survived a complication that occurred during pregnancy, childbirth or within 42 days of termination of pregnancy.

Aims and Objective: To use the new WHO near miss criteria to investigate maternal morbidity and mortality. To determine the Maternal Near Miss Incidence ratio, maternal near miss to mortality ratio and to calculate the mortality index for each event.

Methods: Women showing the presence of any one of the markers in WHO near miss criteria and all maternal deaths from October 2012 to March 2014 were included in the study. The study was conducted in department of Obstetrics and Gynaecology at Lady Hardinge Medical College and SSK Hospital, New Delhi, India.

Observation: There were 19,077 deliveries, 18,631 live births, 161 near miss cases and 35 maternal deaths during the study period. Haemorrhage accounted for most common near miss event (39\%) followed by infection $(28.5 \%)$, anemia $(19.2 \%)$ and eclampsia $(13.3$ $\%)$. The Mortality Index were 33.8\%, $12.5 \%, 6 \%$ and $4.5 \%$ for infection, hypertensive disorder, anemia and haemorrhage respectively. Near miss to maternal death ratio was 4.6:1 and maternal mortality ratio was 188 per $1,00,000$ live birth.

Conclusion: The quality of care received by critically ill obstetric patients in this centre is optimal for near miss events like haemorrhage and anemia as the mortality index were lowest for both events but needs to be improved for infections and hypertensive disorders of pregnancy.

Copy Right, IJAR, 2016,. All rights reserved.

\section{Introduction:-}

Maternal mortality is frequently described as "Just the Tip of The Iceberg" alluding that there is a vast base to the iceberg in the form of maternal near miss i.e. maternal morbidity which has remained largely undescribed.

Large differences were found among countries on the incidence of maternal near miss because of the different settings and variation in the criteria used to define the maternal near miss. In 2009, World Health Organization 
(WHO) defined a maternal near miss case as "A woman who nearly died but survived a complication that occurred during pregnancy, childbirth or within 42 days of termination of pregnancy"[1]

Considering the lack of standardization, WHO in 2009 has developed a set of criteria to identify near miss cases [Table 1][1]. These criteria are intended to be used in any setting, regardless of the development status. The new near miss definition may enable comparison between facilities and over time. Furthermore, relating the proportions of maternal complications, maternal near miss cases and maternal deaths (i.e. mortality index or case fatality ratio) would be useful to assess the quality of care that women with severe complications receive even in tertiary care setting.

Survivors of severe complications related to pregnancy (condition known as maternal near miss cases) have been studied in detail in recent years, mostly in developed countries. But, even in developing countries, information on maternal near miss cases was found to be useful to identify health system failures in maternal health care. [2]This is because near miss cases share many characteristics with maternal deaths and can directly inform on barriers that have to be overcome after the onset of an acute complication. These cases can complement the information obtained from reviewing maternal deaths and function as surrogates of maternal deaths. This will be a useful piece of information in small and medium size health care facilities or settings where few maternal deaths occur [3][4][5].Hence, this study was conducted to provide insight into the quality of maternal care provided in our institution.

\section{Material and Methods:-}

This study was conducted in the Department of Obstetrics and Gynaecology in Lady Hardinge Medical College and S.S.K Hospital, New Delhi for a period of 18 months from October 2012 to March 2014. This is a tertiary care institution, which serves as the major referral centre for other public and private hospitals within New Delhi and nearby states. In addition to providing emergency obstetric services to women referred from other centers, the hospital also provides antenatal care and delivery services for both unreferred low and high risk pregnant women. The hospital provides emergency obstetric and gynecological care for 24 hours a day.

The near miss cases were pregnant and parturient women showing the presence of any one of the markers of life threatening conditions in all the three criteria (clinical, laboratory and management based) given by WHO as shown in Table 1 . All women during pregnancy and up to 42 days post delivery were included in the study. The maternal deaths occurring during the study period were also reviewed.

In the present study, data was collected and extracted retrospectively from the case records by members of study team in a structured performa. All maternal deaths were reviewed as well. Using the provisional and final diagnosis documented in the admission- discharge register of the hospital, case files of women whose diagnoses met the WHO criteria were extracted. Overall, 161 near- miss cases were collected. For each case, information on sociodemographic characteristics, parity, gestational age at the time of the near miss morbidity, educational status, nature of the obstetric complication, presence of organ and/or system dysfunction were collected. Socio-demographic characteristic data, parity and gestational age were compared between the near-miss cases and maternal deaths.

The following near miss indices were calculated -

1. Maternal Mortality Ratio (MMR) calculated using live births as the denominator.

2. Maternal Near Miss Incidence ratio (MNMIR)- Refers to the number of near miss cases per 1000 live births

3. Mortality index for each near miss event in order to evaluate the standard of care provided for each disease category. This is defined as the number of maternal deaths due to a particular obstetric condition divided by the sum of near-miss morbidities and maternal deaths which resulted from this condition, expressed as a percentage. It reflects the proportion of each life-threatening obstetric condition which ended in maternal death. Higher the index indicates poor obstetrics care.

4. Maternal near miss: Mortality ratio- Proportion between maternal near miss cases and maternal death. Higher ratio indicates better care.

Data was analyzed using SPSS software version 17. The study population was characterized using descriptive statistics. The difference between proportions of two groups was analyzed using chi square/fischer exact test. P value $<0.05$ was considered statistically significant. 
Above study was carried out after approval from ethical committee of our institution.

\section{Results:-}

During the 18 months period, there were total 19077 deliveries, 18631 live births, 161 near-miss cases and 35 maternal deaths. This resulted in a MMR of 188/100 000 live births and overall Mortality Index of $17.85 \%$. Maternal near miss incidence ratio was 8.43. Maternal near miss to mortality ratio was 4.6: 1 reflecting a suboptimal care in the institution. $80 \%$ of maternal near miss cases and $86 \%$ of maternal deaths were referred from other health centres.

Demographic characteristics of women who sustained near-miss complications and those who died are comparable as presented in Table 2. Most of the women in each group were within the ages of 21 and 30 years and had gestational age between 29 to 36 weeks. Most of the patients in both the group were unbooked for antenatal care. A booked case is when the pregnant lady has had a minimum of three visits for antenatal checkup after she was registered as per WHO criteria. There was no significant difference in age, parity, educational levels and booking status in the near miss events compared with maternal deaths but for gestational age, significant difference was found.

Hemorrhage accounted for the most common near miss event (39\%), followed by infection (28.5\%), anemia $(19.2 \%)$ and hypertensive disorders (13.3\%) as shown in Table 3.

Most common cause of maternal death was septicemia (65.7\%) followed by hypertensive disorders $(8.6 \%)$ and haemorrhage $(8.6 \%)$ as presented in Table 4 . The mortality index was $33.8 \%, 12.5 \%, 6 \%$ and $4.5 \%$ for infection, hypertensive disorders, anemia and hemorrhage respectively as shown in Table 5.

The nature of organ-system dysfunction/failure and the associated obstetric factors among the near-miss cases and maternal death are shown in Table 6.68 (42.23\%) of near miss cases have organ-system dysfunction. The two most commonly affected organ- system were vascular and cardiac (pulmonary edema) systems.

Table 1:- The WHO Near Miss Criteria

\begin{tabular}{|c|c|c|c|}
\hline Dysfunctional system & Clinical Criteria & Laboratory markers & $\begin{array}{l}\text { Management based } \\
\text { proxies }\end{array}$ \\
\hline Cardiovascular & $\begin{array}{l}\text { Shock } \\
\text { Cardiac Arrest }\end{array}$ & $\begin{array}{l}\mathrm{pH}<7.1 \\
\text { Lactate }>5 \mathrm{mEq} / \mathrm{ml}\end{array}$ & $\begin{array}{l}\text { Use of continuous } \\
\text { vasoactive drugs } \\
\text { Cardio-pulmonary } \\
\text { resuscitation }\end{array}$ \\
\hline Respiratory & $\begin{array}{l}\text { Acute cynosis } \\
\text { Gasping } \\
\text { Respiratory rate>40 or } \\
<6 \text { bpm }\end{array}$ & $\begin{array}{l}\text { Oxygen saturation }<90 \% \text { for } \geq 60 \\
\text { minutes } \\
\mathrm{PaO} 2 / \mathrm{FiO} 2<200 \mathrm{mmHg}\end{array}$ & $\begin{array}{lr}\text { Intubation } & \text { and } \\
\text { ventilation } & \text { not } \\
\text { related to anesthesia }\end{array}$ \\
\hline Renal & $\begin{array}{l}\text { Oliguria non responsive } \\
\text { to fluids or diuretics }\end{array}$ & $\begin{array}{l}\text { Creatinine } \geq 300 \mu \mathrm{mol} / 1 \quad \text { or } \\
\geq 3.5 \mathrm{mg} / \mathrm{dl}\end{array}$ & $\begin{array}{l}\text { Dialysis for acute } \\
\text { renal failure }\end{array}$ \\
\hline $\begin{array}{l}\text { Haematologic/Coagulati } \\
\text { on }\end{array}$ & Failure to form clots & $\begin{array}{l}\text { Acute severe } \\
\text { thrombocytopenia }(<50,000 \\
\text { platelets/ml })\end{array}$ & $\begin{array}{l}\text { Transfusion of } \geq 5 \\
\text { units of blood/ red } \\
\text { cells }\end{array}$ \\
\hline Hepatic & $\begin{array}{l}\text { Jaundice in the presence } \\
\text { of preeclampsia }\end{array}$ & $\begin{array}{l}\text { Bilirubin }>100 \mu \mathrm{mol} / \mathrm{l} \text { or }>6.0 \\
\mathrm{mg} / \mathrm{dl}\end{array}$ & \\
\hline Neurologic & $\begin{array}{l}\text { Any loss of conciousness } \\
\text { lasting }>12 \mathrm{~h} \\
\text { Stroke } \\
\text { Uncontrollable fit/ status } \\
\text { epilepticus } \\
\text { Total paralysis }\end{array}$ & & \\
\hline $\begin{array}{l}\text { Alternative severity } \\
\text { proxy }\end{array}$ & & & $\begin{array}{l}\text { Hysterectomy } \\
\text { following infection } \\
\text { or haemorrhage }\end{array}$ \\
\hline
\end{tabular}


Table 2:- Comparison of demographic characteristic of women with Near Miss Events and Maternal Death

\begin{tabular}{|l|l|l|l|}
\hline Demographic characteristic & $\begin{array}{l}\text { Near miss Event } \\
(\mathrm{n}=161)\end{array}$ & $\begin{array}{l}\text { Maternal death } \\
(\mathrm{n}=35)\end{array}$ & P value \\
\hline Age (Years) & 8 & 5 & 0.05 \\
$<=20$ & 70 & 17 & \\
$21-25$ & 53 & 12 & \\
$26-30$ & 26 & 0 & \\
$31-35$ & 4 & 1 & 0.35 \\
.$>35$ & 59 & 11 & \\
\hline Parity & 77 & 15 & $0.005^{*}$ \\
0 & 25 & 9 & \\
$1-2$ & & & \\
$3-4$ & 22 & 0 & \\
\hline Gestational Age (weeks) & 18 & 11 & \\
$<=12$ & 67 & 14 & \\
$13-28$ & 39 & 5 & 0.18 \\
$29-36$ & 15 & 8 & 0.23 \\
$>=37$ & 72 & 88.2 & \\
Postpartum & 82.4 & & \\
\hline Illiteracy (\%) & & 81 & \\
\hline Booking Status $(\%)$ & & & \\
(Unbooked) & & 5 & \\
\hline
\end{tabular}

$*$ p value $<0.05$

Table 3:- Near Miss Events:

\begin{tabular}{|c|c|c|}
\hline Near Miss Events & Number & Percentage \\
\hline Haemorrhage & 11 & \\
$\circ \quad$ Ectopic & 4 & 39 \\
$\circ \quad$ Abortion & 21 & \\
$\circ$ Placenta Previa & 5 & \\
$\circ \quad$ Abruptio Placenta & 22 & \\
$\circ \quad$ Postpartum Haemorrhage & 63 & \\
$\circ \quad$ Total & 2 & \\
\hline Infection & 3 & \\
$\circ \quad$ Puerperal Sepsis & 3 & \\
$\circ \quad$ Chorioamnionitis & 24 & \\
$\circ \quad$ Septic abortion & 14 & \\
$\circ \quad$ Jaundice & 46 & \\
$\circ \quad$ Others & 31 & 19.2 \\
$\circ \quad$ Total & 21 & \\
\hline Anemia & & \\
\hline Hypertensive Disorders & 161 & \\
Eclampsia & & \\
Pre eclampsia & & \\
\hline Total & & \\
\hline
\end{tabular}

Table 4:- Causes of Maternal Mortality

\begin{tabular}{|c|c|c|}
\hline Factor & Maternal Death & Percentage \\
\hline Haemorrhage & 3 & 8.6 \\
\hline Septicemia & 23 & 55.7 \\
\hline Anemia & 2 & 5.7 \\
\hline Heart Disease & 2 & 5.7 \\
\hline Hypertensive Disorder & 3 & 5.6 \\
\hline Amniotic fluid Embolism & 2 & 100 \\
\hline Total & 35 & \multicolumn{2}{c|}{} \\
\hline
\end{tabular}


Table 5:- The Mortality Index of Near Miss Events:

\begin{tabular}{|c|c|c|c|}
\hline Event & Near Miss & Death & Mortality Index (\%) \\
\hline Haemorrhage & 63 & 3 & 23 \\
\hline Septicemia & 46 & 2 & 63.8 \\
\hline Anemia & 31 & 2 & 0 \\
\hline Heart Disease & 0 & 2 & 0 \\
\hline Amniotic fluid Embolism & 0 & 3 & 12.5 \\
\hline
\end{tabular}

Table 6:- Organ System Dysfunction in Near Miss Events and Maternal Death

\begin{tabular}{|c|c|c|c|c|}
\hline Organ-System & $\begin{array}{l}\text { Near Miss Event } \\
(n=161)\end{array}$ & Obstetric Cause & $\begin{array}{l}\text { Maternal } \\
\text { Death } \\
(n=35)\end{array}$ & Obstetric Cause \\
\hline $\begin{array}{l}\text { 1.Cardiac (Pulmonery } \\
\text { edema) }\end{array}$ & 43 & $\begin{array}{l}\text { S. Anemia (26) } \\
\text { S. Pre eclampsia ( 9) } \\
\text { Eclampsia ( 8) }\end{array}$ & 5 & $\begin{array}{l}\text { S. Anemia (2) } \\
\text { S. Pre eclampsia (2) } \\
\text { RHD* (1) }\end{array}$ \\
\hline 2. Coagulation & 8 & Jaundice (8) & 5 & $\begin{array}{l}\text { Hepatic } \\
\text { Encephalopathy(5) }\end{array}$ \\
\hline 3. Renal & 7 & $\begin{array}{l}\text { Puerperal Sepsis(2) } \\
\text { S. Preeclampsia(2) } \\
\text { Abruption(1) } \\
\text { Atonic PPH** (1) } \\
\text { Chorioamnionitis(1) }\end{array}$ & 3 & $\begin{array}{l}\text { Hepatic } \\
\text { Encephalopathy(2) } \\
\text { S. Preeclampsia(1) }\end{array}$ \\
\hline 4. Vascular & 35 & $\begin{array}{l}\text { Rup ectopic preg (11) } \\
\text { Uterine Rupture (2) } \\
\text { PPH (22) }\end{array}$ & 5 & $\begin{array}{l}\text { Amniotic fluid } \\
\text { embolism (2) } \\
\text { PPH (3) }\end{array}$ \\
\hline 5. Respiratory & 9 & LRTI $* * *(9)$ & 13 & ARDS****(13) \\
\hline 6. Cerebral & 1 & Traumatic Quadriplegia (1) & 3 & $\begin{array}{l}\text { Tubercular } \\
\text { meningitis (2) } \\
\text { Eclampsia (1) }\end{array}$ \\
\hline 7. Hysterectomy & 22 & $\begin{array}{l}\text { Placenta percreta }(8) \\
\text { Placenta previa }+\mathrm{PPH}(7) \\
\text { Retained placenta }+\mathrm{PPH}(3) \\
\text { Rupture Uterus }+\mathrm{PPH}(2) \\
\text { Abruption }+\mathrm{PPH}(2)\end{array}$ & 2 & $\begin{array}{l}\text { Rupture Uterus + } \\
\text { PPH (1) } \\
\text { Atonic PPH(1) }\end{array}$ \\
\hline
\end{tabular}

*Rheumatic heart disease

**Post partum haemorrhage

$* * *$ Lower respiratory tract infection

****Acute Respiratory distress syndrome

Table 7:- Comparison of various studies in Near Miss Events and Maternal Death

\begin{tabular}{|l|l|l|c|}
\hline STUDY & $\begin{array}{l}\text { MOST COMMON NEAR } \\
\text { MISS EVENT }\end{array}$ & $\begin{array}{l}\text { MOST COMMON } \\
\text { CAUSE OF DEATH }\end{array}$ & MORTALITY INDEX \\
\hline $\begin{array}{l}\text { Mental et al (S.Africa) } \\
1998\end{array}$ & $\begin{array}{l}\text { Hypertention(26\%) } \\
\text { Haemorrhage( 26\%) }\end{array}$ & $\begin{array}{l}\text { Hypertention (33\%) } \\
\text { Infection }(27 \%)\end{array}$ & - \\
\hline $\begin{array}{l}\text { Oladapo et al } \\
\text { Nigeria) 2005 }\end{array}$ & $\begin{array}{l}\text { Hypertention(31\%) } \\
\text { Haemorrhage(30\%) }\end{array}$ & $\begin{array}{l}\text { Hypertention(30\%) } \\
\text { Haemorrhage(21\%) }\end{array}$ & - \\
\hline $\begin{array}{l}\text { Mustafa et al } \\
\text { Karachi) 2009 }\end{array}$ & Haemorrhage(51\%) & Haemorrhage(83.3\%) & $\begin{array}{l}\text { Infection (33.3\%) } \\
\text { Haemorrhage }(17.2 \%)\end{array}$ \\
\hline $\begin{array}{l}\text { Adbel et al } \\
\text { Sudan)2011 }\end{array}$ & Haemorrhage(41\%) & $\begin{array}{l}\text { Infection (35\%) } \\
\text { Haemorrhage }(23 \%)\end{array}$ & $\begin{array}{l}\text { Infection }(22.2 \%) \\
\text { Haemorrhage }(8.8 \%)\end{array}$ \\
\hline $\begin{array}{l}\text { Fatima et al (Brazil) 2012 } \\
\text { Raemorrhage (40\%) }\end{array}$ & Overall 10.4\% \\
\hline Roopa et al (India) 2013 & Haemorrhage (44.2\%) & Infection (52.2\%) & Overall 14.9\% \\
\hline
\end{tabular}




\begin{tabular}{|l|l|l|l|}
\hline & Hypertension (23.6\%) & & Infection (36.3\%) \\
\hline $\begin{array}{l}\text { Souza et al (WHOMCS) } \\
2013\end{array}$ & $\begin{array}{l}\text { Haemorrhage (26.7\%) } \\
\text { Hypertension (25.9\%) }\end{array}$ & - & Overall 16.07\% \\
\hline Present Study & $\begin{array}{l}\text { Haemorrhage (39\%) } \\
\text { Infection (28.5\%) }\end{array}$ & Infection (65.7\%) & $\begin{array}{l}\text { Overall 17.8\% } \\
\text { Infection (33.8\%) }\end{array}$ \\
\hline
\end{tabular}

*WHO Multicountry Survey

\section{Discussion:-}

Maternal mortality was used to assess the quality of obstetric care but this indicator is vulnerable to many flaws. A better assessment of obstetrical care now includes near miss events to be a useful complement tool for investigation of maternal mortality. Hence new "near miss" criteria take over maternal mortality ratio. In 2008, WHO recommended investigating near miss as a benchmark tool for monitoring maternal health care and has standardized the criteria for diagnosis. WHO criteria are unique in considering not only clinical but also laboratory and management based criteria.

A statistically significant difference was found between near miss events and maternal deaths as regard the gestational age because none of maternal deaths occurred before 12 weeks of gestation (Table 2).

In the present study, maternal mortality to near miss ratio was 1:4.6. This indicates that for every almost 5 women who survived life threatening complications, one died. This reflects a poor care and high maternal mortality in this setting. Other studies found the maternal death to near miss ratio as 1:5 and 1:7 respectively.[6][7] This is in contrast to what is observed in developed countries of the world. Studies carried out in Europe revealed a ratio of 1:117$223[8[[9]$.This ratio is indicative of the standard of obstetrical care. If this ratio decreases over a period of time, it reflects on the improvement achieved in obstetric care.

The most common near miss event in the present study was haemorrhage (39\%) followed by infection (28.5\%), anemia (19.2\%) and hypertensive disorder (13.3\%). The result were in accordance with various studies [10][11][12][13][14] where haemorrhage was the most common near miss event. In contrast to other studies, [6][15] hypertension was most common near miss event.

The most common cause of maternal mortality was septicemia (65.7\%) followed by hypertensive disorders (8.6\%) and haemorrhage (8.6\%) in the present study. Similar results were seen in study conducted in south India [13].The maternal mortality ratio at our setting was $188 / 100000$ live births. The Brazilian study showed a similar mortality rate of 260/100000 live births [16]. In other developing countries the maternal mortality ratios were 423/100000 live births and 324/100000 live births respectively [17][18]. The major cause of maternal mortality was infectious diseases like tuberculosis, pneumonia and hepatic encephalopathy which were not related to pregnancy. There were three deaths due to haemorrhage and three deaths due to hypertensive disorder complicated with pulmonary edema and renal failure. Most of the maternal death were unpreventable in the present study as they occur in unbooked emergency cases that present too late to the hospital and die shortly after admission.

In this setting, the health care providers were faced with a high percentage of life- threatening obstetric situations. Despite the high morbidity from haemorrhage and anaemia (39\%, 19.2\% respectively) their mortality index was lower than that of the other events. This is due to presence of trained personnel, strict adherence to evidence based protocol and availability of all sorts of blood and blood products round the clock in the hospital. An increased level of care and effort are required to deal with near-miss events with high mortality index, e.g., infection and hypertensive disorder.

Lack of antenatal care services in peripheral health care centre, illiteracy, delayed diagnosis, late transfer, and inadequate utilization of resources might have been the cause for maternal morbidities and mortalities in our study.

One of the limitations of this study is weakness of retrospective method of data collection with respect to the quality of records. Other limitation is that ours is a tertiary referral center covering two nearby states, with most of the cases being referred from other health care centre in an already moribund state. The delays in referrals are a major cause of morbidity and mortality. Table 7 shows comparison of various studies in near miss and maternal death. 


\section{Conclusion:-}

The quality of care received by critically ill obstetric patients in this centre is optimal for near miss events like haemorrhage and anemia as the mortality index were lowest for both events but needs to be improved for infections and hypertensive disorders of pregnancy. In a tertiary care hospital, it is possible to save most of the patients presenting with life threatening conditions by adopting evidence based protocol, training of personnel, improving the resources and multidisciplinary approach for managing severe morbidities. Overall reduction in maternal mortality can be achieved by improving the antenatal care and timely referral of cases to tertiary care hospital thus aiming to meet the Sustainable Development Goal 3.

\section{Financial support and Sponsorship:-}

Nil

\section{Conflicts of Interest:-}

There are no conflicts of interest

\section{References:-}

1. Report on the World Health Organization Working Group on the classification of Maternal Deaths and Severe Maternal Morbidities. Geneva: World Health Organization, 2009.

2. Filippi $\mathrm{V}$ et al.Obstetric audit in resource-poor settings: lessons from a multi-country project auditing 'near miss' obstetrical emergencies. Health Policy Plan 2004;19 (1):57-66

3. Say L, Pattinson RC, Gulmezoglu AM. WHO systematic review of maternal morbidity and mortality: the prevalence of severe acute maternal morbidity (near miss). Reprod Health 2004; 1(1):3

4. Pattinson RC, Hall M. Near misses: a useful adjunct to maternal death enquiries. Br Med Bull 2003; 67:231243.

5. Cochet L, Pattinson RC, Macdonald AP. Severe acute maternal morbidity and maternal death audit- a rapid diagnostic tool for evaluating maternal care. S Afr Med J 2003; 93(9):700-702.

6. Oladapo OT, Sule-Odu AO, Olatunji AO, Daniel OJ. "Near-miss"obstetric events and maternal deaths in Sagamu, Nigeria: a retrospective study. Reprod Health 2005; $2: 1186-95$.

7. Pandey M, Mantel GD, Moodley J. Audit of severe acute morbidity in hypertensive pregnancies in a developing country. J Obstet Gynaecol 2004; 24: 387-391.

8. Waterstone M, Bewley S, Wolfe C. Incidence and predictors of severe obstetrics morbidity: case-control study. BMJ 2001; 322:1089-1094.

9. Minkauskiene M, Nadisauskiene R, Padaiger Z, Makari S. Systemic review on the incidence and prevalence of severe maternal morbidity. Medicina (Kuanas) 2004; 40: 299-309.

10. Lotufo FA, Parpinelli MA, Haddad SM, Surita FG, and Cecatti JG. Applying the concept of maternal near-miss in an intensive care unit. Clinics (Sao Paulo) 2012; 67(3): 225-230.

11. Rozina M, Haleema H.Near-Miss Obstetrical Events and Maternal Deaths. Journal of the college of Physicians and surgeons Pakistan 2009;19 (12):781-785

12. Abdel A, Awadia K, Amira O, Gamal K, Ishag A. Maternal near-miss in a rural hospital in Sudan. BMC Pregnancy Childbirth. 2011; 11:48.

13. Roopa PS et al."Near Miss" Obstetric Events and Maternal Deaths in a Tertiary Care Hospital: An Audit. J Pregnancy2013;393758

14. Souza JP, Gulmezoglu AM, Vogel J, Carroli G, Lumbiganon P, Qureshi Z, et al. Moving beyond essential interventions for reduction of Maternal mortality: a cross-sectionnal study. Lancet 2013; 381:1747-55.

15. Mentel GD, Buchmann E, Rees H, Pattinson RC. Severe acute maternal morbidity: a pilot study of a definition for a near-miss. Br J Obstet Gynaecol 1999; 106:397.

16. Souza JP, Cecatti JG,. Parpinelli MA, Serruya SJ, and Amaral E. "Appropriate criteria for identification of nearmiss maternal morbidity in tertiary care facilities: a cross sectional study," BMC Pregnancy and Childbirth 2007; 7 (20): 1-8

17. Shrestha NS, Saha R, Karki C. "Near miss maternal morbidity and maternal mortality at Kathmandu Medical College Teaching Hospital," Kathmandu University Medical Journal 2010;8(30): 222-226

18. Almerie Y, Almerie M.Q, MatarH.E, Shahrour Y, Chamat A, Abdulsalam A. “Obstetric near-miss and maternal mortality in maternity university hospital, Damascus, Syria: a retrospective study," BMC Pregnancy and Childbirth 2010; 10 (65): 2-7. 